Rapp. Grønlands geol. Unders. 48, 75-83 (1972)

\title{
PRELIMINARY REPORT ON THE BASALTS OF VOLQUART BOONS KYST, EAST GREENLAND
}

\author{
W. Stuart Watt, C. H. Emeleus and Margrethe Watt
}

\section{Introduction}

The area between Helgenæs and Kap Brewster, a total of approximately $2000 \mathrm{~km}^{2}$ (north of $70^{\circ} \mathrm{N}$ ) was mapped systematically by two parties, and selected reconnaissance traverses were made in adjacent areas south of $70^{\circ}$ in order to obtain a clearer picture of the regional structure.

The northern part of the area consists of almost vertical, north-facing cliffs rising to over $1000 \mathrm{~m}$ stretching for $120 \mathrm{~km}$ interrupted by hanging glaciers. In the east these cliffs drop to about $300 \mathrm{~m}$ at Kap Brewster and to low cliffs and beaches on the south-east coast of Savoia Halvø. The zone of hanging glaciers presented a particular problem since they hide the exposure at a fairly constant level from about 1000 to $1200 \mathrm{~m}$ (plateau level) making traversing and correlation possibilities at this height very limited. Inland the area is covered by the ice cap from which nunataks rise to $2000 \mathrm{~m}$.

Exposure is generally excellent, except on Savoia Halvø which has large areas of drift, but access is often made impossible by vertical cliffs and intervening glaciers. Hence much of the map-making was done on helicopter reconnaissances supported by detailed profiles at 15 to $20 \mathrm{~km}$ intervals.

To the south-east the nunataks continue till they reach the coastal range of the Blosseville Kyst. On a visit to warm springs at Rømer Fjord a brief investigation was made of the supposed coastal flexure in relation to the structure of the inland area.

The area consists almost entirely of horizontal or sub-horizontal flows with a total thickness of approximately $\mathbf{2 0 0 0} \mathrm{m}$, consisting of more than $\mathbf{5 0}$ flows or flow groups. The lateral extent of the flows will be dealt with later. With rare exceptions the flows were extruded under subaerial conditions. A slight disconformity was recorded in the region of Søstrene. 


\section{Flow description}

\section{Single flows}

Massive, non-vesicular basaltic lava makes up the majority of the single flows. True, regular, columnar jointing is mostly confined to relatively thick flows, but can occasionally be seen in thinner flows (about $10 \mathrm{~m}$ ) or locally where a flow has filled a depression in the underlying flow. A two-fold division of the massive part of the flow into a lower colonnade markedly divided from an upper entablature consisting of tiers of thinner, of ten very regular, columns is common. This phenomenon can be repeated within the same flow, but rarely more than two or three times. The relative proportions of colonnade and entablature is very variable from flow to flow.

\section{Flow groups}

By flow groups are meant a number of usually very thin flows or units presumably belonging to one volcanic event but often separated by thin, discontinuous, red-coloured, chilled horizons. They are frequently associated with pahoehoe features (filamented or ropy tops and rounded vesicles). The individual units mostly consist of vesicular lava with horizontally arranged vesicles.

These groups are rarely columnar jointed and generally show rounded weathering features. The weathering colour is often a dark brown (never redbrown), but as the numerous vesicles are mostly filled with zeolitic material these flow groups often have a light grey appearance from a distance - hence the term 'grey series'.

\section{Pillow lava and hyaloclastics}

Pillow lava and hyaloclastics may be more common than the scattered outcrops indicate and are more often seen by chance due to bad exposure than by systematic searching. Extensive outcrops have only been examined in the Vikingebugt region where they occur at at least three horizons, and on Kamelryggen and Rejedal. At Helgenæs an outcrop reaches $50 \mathrm{~m}$ in thickness, composed of basalt fragments generally not larger than $2 \mathrm{~cm}$, mostly smaller, decreasing in size towards the top of the outcrop which weathers into a yellow or brown scree. At Kamelryggen pillow lavas are up to $42 \mathrm{~m}$ in thickness.

Pillow lavas do not appear to be continuous, but similar rocks are reported from about $1000 \mathrm{~m}$ altitude on Pyramiden (Fawcett et al., 1966) and south of the huts at Kap Brewster (C.K. Brooks, personal communication). 


\section{Sediments}

Sediments are present at a number of localities on Savoia Halvø throughout the lava succession, and especially in the upper parts where there are thin shale seams often together with poor coal and plant remains. A band of well-indurated, coarse sandstone with detrital garnet was mapped about $150 \mathrm{~m}$ above the base of the lavas near the Kap Brewster settlement, dying out to the south from a maximum of about $15 \mathrm{~m}$. At the settlement dark grey, badly weathered shales outcrop up to about $70 \mathrm{~m}$. These underlie the lavas but are extremely poorly exposed; they differ from the later sediments at Krabbedalen in that they are micaceous and relatively well indurated (see also Birkenmajer, this report). A Mesozoic age was suggested for these by Hassan (1953). Fossiliferous sandstones, silty sandstones and siltstones with marly mudstone layers and carbonate-rich, concretionary nodules are excellently exposed in Krabbedalen, on the NE side of Kikiakajik, at several points on the south of the Kamelryggen peninsula, and on the SE side of Sfinksen. These owe their preservation to faulting. The sediments at Krabbedalen rest on an eroded lava surface with lava boulders in their lower part, and at no place was this type of sediment found definitely overlain by lava flows. Igneous debris in the sediments include bipyramidal quartz, sanidine and biotite, as well as basalt, suggesting acid igneous activity in the area but not represented in the lava succession examined.

\section{Field petrography}

Most of the basalts in the area may be characterised as fine grained, some very fine, others, particularly the so-called 'grey series' of vesicular flow units seem to be coarser, though small variations in grain size seem relatively common within the same flow. In the uppermost part of the sequence (at Skrænterne) thin pegmatitic bands form almost a network throughout the massive part of a thick flow, a feature also present in the same flow $20 \mathrm{~km}$ farther south. Similar features occur in flows on Kamelryggen and on Søstrene close to the huts at Bopladsdalen.

One of the most marked features in the field was the presence, size and arrangement of plagioclase phenocrysts. Only very few of the flows examined can be characterised as non-porphyritic; most of these are found in the central part of the sequence, but do not form a clear stratigraphic horizon.

The majority of the flows contain plagioclase phenocrysts varying in size from 1 to $30 \mathrm{~mm}$, mostly forming aggregates commonly about $5 \mathrm{~mm}$ in diameter; occasional flows have aggregates to $10 \mathrm{~cm}$.

A large number of flows may be referred to as slightly porphyritic containing scattered phenocryst aggregates up to $5 \mathrm{~mm}$. Along with the non-porphyritic they make up the majority of the sequence in the western part of the area, while flows with larger and denser phenocrysts increase in number eastwards. 
A single flow present from Borgvig eastwards contains exceptionally large, starshaped aggregates up to $80 \mathrm{~mm}$ across.

The uppermost 600 to $700 \mathrm{~m}$ of the total succession (above the lower grey series') which is present on the inland nunataks, shows a gradual decrease upwards in size and density of the phenocrysts over a span of 12 to 14 consecutive flows from numerous 5 to $15 \mathrm{~mm}$ aggregates down to scattered 2 to $4 \mathrm{~mm}$ aggregates.

The lowest flows at Helgenæs, which stratigraphically seem to be the lowest flows in the area discussed, are fairly porphyritic and appear to form the top part of the 'lower' porphyritic sequence previously investigated in the Sydbræ region to the south-west (Watt, 1969). In the Sydbræ region a division between a lower very porphyritic sequence of flows (with plagioclase phenocrysts up to 3 to $4 \mathrm{~mm}$ ) and an upper almost completely non-porphyritic sequence of more than $1000 \mathrm{~m}$ is very marked. A similar clear division has been observed on Gåseland and Milne Land. For the Kap Dalton region Wager has suggested a two-fold division with lower mainly porphyritic lavas and upper mainly non-porphyritic (1934, p. 30). The only previous description of the coastal zone between Kap Dalton and Kap Brewster is that of Nordenskjöld who described these lavas as mainly non-porphyritic (1907, p. 220).

Normally the number and size of phenocrysts seem relatively constant both along the lateral extent of a flow as well as on a vertical scale, though a few exceptions have been recorded. In a couple of flows phenocrysts were extremely rare near the base of the flow but increase gradually in number upwards.

Occasionally, small augite phenocrysts are also present but are decidedly uncommon, except low in the sequence.

\section{Lateral extent of flows}

Only the uppermost lavas were suitably exposed to attempt a study of the lateral extent of individual flows. Even so, frequent gaps of 5 to $10 \mathrm{~km}$ between exposures obscure the picture for the thinner and less conspicuous flows.

It was found that the thickness of brecciated (aa) tops in relation to the massive part of the flows was the most consistent feature within the individual flows. Other features such as columnar and entablature formation could be used over shorter distances but are affected by thickness of flow and possibly by distance from its source. Tuff horizons were often found to be of no help except very locally due to poor exposure and discontinuity.

One of the flow groups, where examined, appears to consist of up to three individual flows plus a variable number of thin units attached to the upper part of the group. Towards the south-east the units seem to merge into one distinct flow showing a gradual development of a massive colonnade below a dark entablature. This flow group has a lateral extent of more than $2000 \mathrm{~km}^{2}$. 
The same minimum extent was measured for at least two single flows with thicknesses of 70 and $35 \mathrm{~m}$ respectively, giving minimum volumes of 140 and 70 $\mathrm{km}^{3}$.

A third single flow near the top of the succession covers an area of at least $14-1500 \mathrm{~km}^{2}$ without showing signs of thinning markedly in any direction. This, coupled with the exceptional thickness of nearly $100 \mathrm{~m}$, gives an approximate minimum volume of $140 \mathrm{~km}^{3}$.

The 'upper grey series' and at least one single flow were seen with certainty to have travelled more than $75 \mathrm{~km}$ in one direction, measured from the bottom of Rømer Fjord to a nunatak south of Vikingebugt. To the north-east the exposures end above Volquart Boons Kyst and to the south-west they disappear under the ice cap, reflecting the limits of the outcrop rather than the limit of the flows, the extent of which were only followed $45 \mathrm{~km}$ south from Volquart Boons Kyst.

A number of the thinner flows were occasionally seen to die out. Two flows present on the nunatak south of Skrænterne were seen, at least locally, to thicken to the west. In most cases, however, the limit of a flow was only observed in one locality and hence it is impossible to give more than an approximate determination of the direction of thickening.

For the majority of the flows in the lower part of the sequence it is impossible to obtain a three-dimensional picture of their lateral extent since they are only exposed in a narrow strip along Volquart Boons Kyst. Flows with distinctive features could be followed along the coast for up to 50 to $70 \mathrm{~km}$ in a WNW-ESE direction, many for 15 to $20 \mathrm{~km}$, indicating that the earlier lava flows also spread over large areas.

\section{Structural observations}

The structure of the area north-west of Bartholins Bræ (fig. 12) is extremely simple with an average overall SE dip of $1^{\circ}$ although local westerly or north-westerly components were observed in the Skrænterne area and in the coastal zone east of Borgvig, but again not exceeding 1 to $11^{\circ}$. The area north-west of Bartholins Bræ is largely unfaulted although a pair of small, normal faults cut Langryggen and were also seen on a nunatak $25 \mathrm{~km}$ to the SW following a NE-SW glacier. The throw is only about $25 \mathrm{~m}$ to the SE.

Towards the south-east the faulting gradually becomes more intense starting with a group of small faults on the NW edge of Bartholins Bræ, also trending NESW and clearly seen on the north-facing wall of Pindsvinet, with at least four fracture zones with throws not exceeding 50 to $100 \mathrm{~m}$ both to the NE and SW.

In the coastal zone south-east of Bartholins Bræ the faulting becomes more intense associated with steeper dips of the basalts and a gradually denser dyke swarm. Neither Bartholins Bræ nor Stenos Gletscher seem to be associated with any 


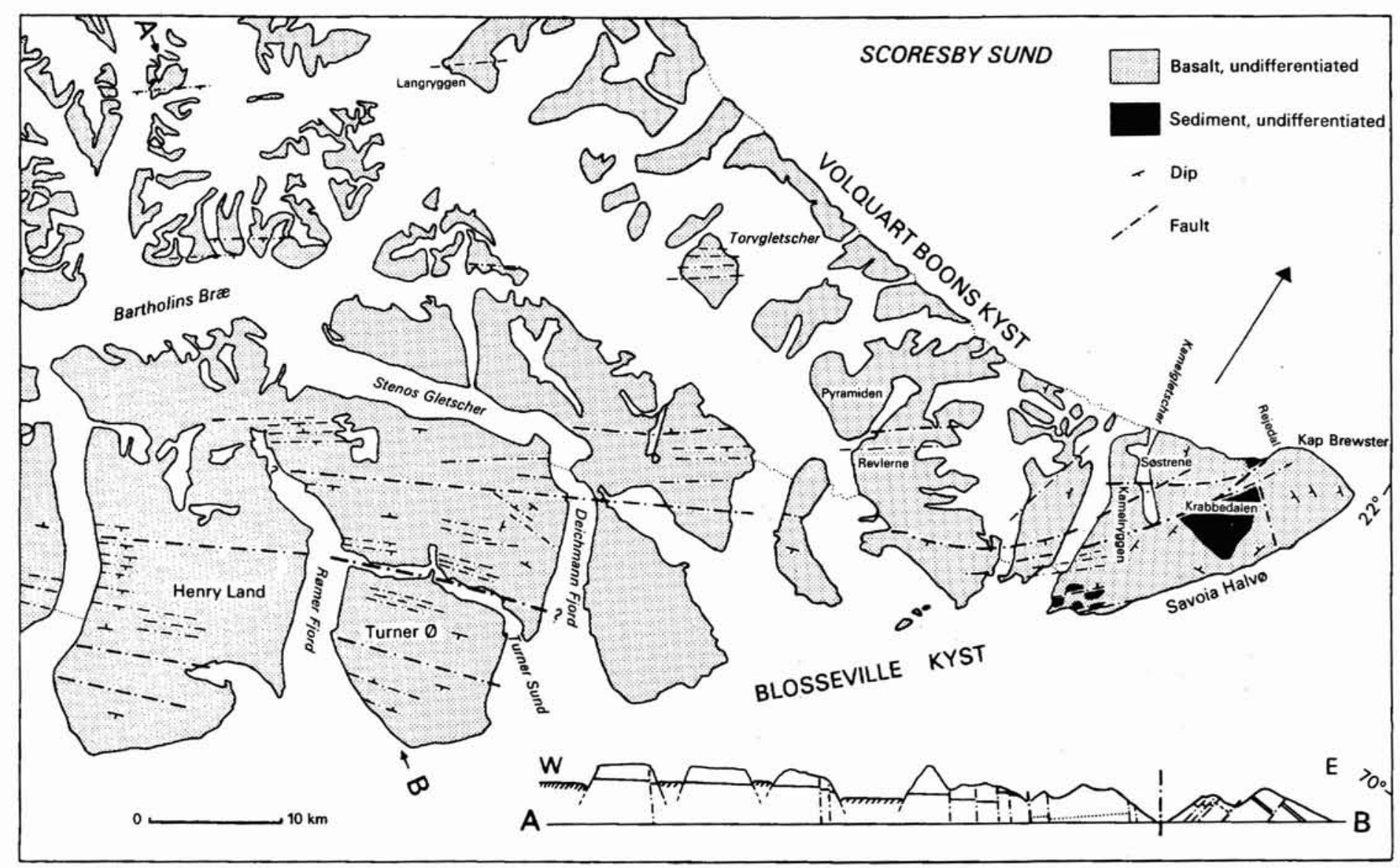

Fig. 12. Sketch-map of the structure of the northern part of the Blosseville Kyst, based partly on interpretation from aerial photographs. The vertical exaggeration on the cross-section $\times 21 / 2$. 
large-scale displacement as the uppermost basalt sequence was recognised on both sides of these marked coast-parallel features at much the same height.

A small group of faults at the northern end of Stenos Gletscher can be matched at Revleren to the north-east. An apparently larger throw to the SE was seen near the head of Rømer Fjord followed seawards by inland-dipping $\left(5^{\circ}\right.$ to $\left.8^{\circ}\right)$ basalt with minor faulting with throws to the SE. The most striking tectonic features were seen across Savoia Halvø and along Turner Sund which form divisions between inland-dipping basalts and a seaward dip of up to $40^{\circ}$ on Turner $\emptyset$. The amount and direction of movement along these features is unknown but may be considerable.

A generalised cross-section from Turner $\emptyset$ to Skrænterne is shown on fig 12 . From aerial photographs the zones of minor faulting can be seen to continue to the south-west on Henry Land. The outer part of Henry Land dips seawards but not as steeply as Turner $\emptyset$ and the postulated fault causing the marked change of dip observed at Turner Sund is not obviously matched on the south-west side of Rømer Fjord, but appears to lie farther south-east (seaward) on Henry Land, possibly reflecting an en échelon development. In the area between Deichmann Fjord and Savoia Halvø south of Kap Brewster the fault pattern is somewhat obscured by poor exposure.

Generally speaking the picture as it stands out along the northern part of the Blosseville Kyst is that of en échelon faulting, possibly of strike-slip fault origin, following a more complicated pattern than that suggested for the Blosseville Kyst west of Kap Dalton by Wager \& Deer (1938), but a good deal more detailed work is required to gain a full understanding of the area.

\section{Dykes}

Dykes are extremely rare in the area north-west of Bartholins Bræ but are very common south-east of this glacier trending parallel to the coast. On Turner $\emptyset$ the density is more than 25 dykes per $10 \mathrm{~km}$, while north-west of Turner Sund the number appears to drop to about half, but as this zone is less well exposed the number may well be higher. From the head of Rømer Fjord inland, the dyke density decreases rapidly. North and north-east of Stenos Gletscher the dyke swarm thins. No dykes (or other minor intrusions) are reported from Savoia Halvø, but a few dykes with a more E-W orientation were seen north-east of Stenos Gletscher indicating the possibility that the thinning dyke swarm swings out to sea before reaching the Kap Brewster area. The dykes seem largely to follow the fault planes, being intruded approximately perpendicular to the lava surfaces. The few dykes studied did not seem to differ petrographically from the surrounding flows, but there is no obvious indication that these dykes have acted as feeders for the basalts and all dykes seen appear to cut the entire exposed lava pile. 


\section{Palaeomagnetic field observations}

A preliminary investigation of the remanent magnetisation was made in the field using a hand compass as a continuation of the encouraging results from previous years (Watt \& Watt, 1971).

A total of $\mathbf{8 1 5}$ measurements were taken in the region of unfaulted lavas distributed over 12 traverses covering 160 flows (averaging 5.1 readings a flow). Out of the 815 readings $38 \%$ were normally magnetised, $53 \%$ reversely magnetised and $9 \%$ were insufficiently magnetised to give a reading. As the total sequence in any given place only numbers about 50 flows or flow groups a considerable overlap is to be expected. From field evidence a number of flows, particularly in the lower part of the sequence are known to have been traversed three to five times. This provides an excellent opportunity to test the consistency of the method based on a higher number of readings than the recommended minimum of three (Abrahamsen, 1967). Out of 8 single flows with good correlation controlsome of them marker flows -7 were dominantly reversely magnetised and one, low in the succession, dominantly normal. In all except one case the reproducibility of the magnetic measurements within a single flow exceeds $67 \%$. Where correlation control is less good, or where a flow was only crossed twice, the picture is much the same. Only rarely did a flow give completely consistent readings at all localities, but there is often a clear dominance, in most cases reversely magnetised.

There seems to be no clear division into zones of different polarity. The fact that most of the flows in this region (as opposed to, e.g. Milne Land and NW Gåseland (Watt \& Watt, 1971)) give mixed results may be interpreted as an indication of unstable magnetisation as already suggested for part of this region by Tarling (1967).

\section{References}

Abrahamsen, N. 1967: Some paleomagnetic investigations in the Faroe Islands. Meddr dansk geol. Foren. 17, 371-384.

Fawcett, J. J., Rucklidge, J.C. \& Brooks, C. K. 1966: Geological expedition to the Tertiary basalt region of Scoresby Sund, East Greenland. Nature, Lond. 212, 603-604.

Hassan, M. Y. 1955: Tertiary faunas from Kap Brewster, East Greenland. Meddr Grønland $111,5$.

Nordenskjöld, O. 1907: On the geology and physical geography of East Greenland. Meddr Gronland 25, 151-284.

Tarling, D. H. 1967: The palaeomagnetic properties of some Tertiary lavas from East Greenland. Earth planet. Sci. Lett. 3, 81-88.

Wager, L. R. \& Deer, W. A. 1938: A dyke swarm and crustal flexure in East Greenland. Geol. Mag. 75, 39-46. 
Watt, W.S. 1969: The Tertiary basalts of Scoresby Sund, a preliminary report. Rapp. Gronlands geol. Unders. 21, 36-40.

Watt, W. S. \& Watt, M. 1971: Preliminary report of the mapping of the basalts of parts of Milne Land and Gåseland. Rapp. Grønlands geol. Unders. 37, 42-50.

Wager, L. R. 1934: Geological investigations in East Greenland. Part I. General geology from Angmagsalik to Kap Dalton. Meddr Gronland 105, 2. 